\title{
Biological and physicochemical stability of ceftazidime and aminophylline on glucose parenteral solution
}

\author{
Carolina Alves dos Santos*, Laura Oliveira-Nascimento, Marcos Camargo Knirsch, \\ Marco Antônio Stephano, Adalberto Pessoa Júnior, Thereza Christina Vessoni Penna
}

School of Pharmaceutical Sciences, University of São Paulo, São Paulo, SP

\begin{abstract}
Ceftazidime is a broad spectrum antibiotic administered mainly by the parenteral route, and it is especially effective against Pseudomonas aeruginosa. The period of time in which serum levels exceed the Minimum Inhibitory Concentration (MIC) is an important pharmacodynamic parameter for its efficacy. One of the forms to extend this period is to administer the antibiotic by continuous infusion, after prior dilution in a Parenteral Solution (PS). The present work assessed the stability of ceftazidime in 5\% glucose PS for 24 hours, combined or not with aminophylline, through High Performance Liquid Chromatography (HPLC). The physicochemical evaluation was accompanied by in vitro antimicrobial activity compared MIC test in the 24-hour period. Escherichia coli and Pseudomonas aeruginosa were the microorganisms chosen for the MIC comparison. The HPLC analysis confirmed ceftazidime and aminophylline individual stability on PS, while the MIC values were slightly higher than the mean described in the literature. When both drugs were associated in the same PS, the ceftazidime concentration by HPLC decreased $25 \%$ after 24 hours. Not only did the MIC values show high loss of antibiotic activity within the same period, but also altered MIC values immediately after the preparation, which was not detected by HPLC. Our results indicate that this drug combination is not compatible, even if used right away, and that PS might not be the best vehicle for ceftazidime, emphasizing the importance of the MIC evaluation for drug interactions.
\end{abstract}

Uniterms: Drug/interactions. Injectables. Parenteral solutions. Ceftazidime/stability. Aminophylline/ stability. High Performance Liquid Chromatography/quantitative analysis. Minimum inhibitory concentration (MIC).

Ceftazidima é um antimicrobiano administrado por via parenteral, que apresenta amplo espectro de ação, principalmente contra Pseudomonas aeruginosa. O tempo em que a concentração sérica de ceftazidima permanece acima da concentração mínima inibitória (MIC) é um importante parâmetro farmacodinâmico para a determinação da eficácia antimicrobiana e pode ser potencializado através da utilização de infusão contínua em soluções parenterais (PS). Este artigo visa a avaliar a estabilidade da ceftazidima em solução de glicose 5\%, na presença e na ausência do fármaco aminofilina, através de cromatografia líquida de alta eficiência HPLC e MIC durante o período de 24 horas. Os microorganismos selecionados para a determinação do MIC foram Escherichia coli e Pseudomonas aeruginosa. Os ensaios em cromatógrafo líquido confirmaram a estabilidade dos fármacos ceftazidima e aminofilina quando são individualmente associados em PS, enquanto os valores de MIC ficaram maiores que os valores encontrados na literatura. Quando ambos os fármacos foram associados na mesma solução parenteral a concentração de ceftazidima obtida por HPLC diminuiu 25\% depois de 24 horas. Os valores de MIC mostraram maior decaimento da atividade antimicrobiana neste mesmo período e também valores de MIC alterados nas soluções preparadas no tempo zero, decaimento este que não foi detectado em HPLC. Os resultados indicaram incompatibilidade na associação dos fármacos em PS, enfatizando a importância dos resultados de MIC para interações de fármacos.

Unitermos: Fármacos/interação. Injetáveis. Soluções parenterais. Ceftazidima/estabilidade. Aminofilina/ estabilidade. Cromatografia Líquida de Alto Desempenho/análise quantitativa. Concentração Inibitória Mínima (MIC).

\footnotetext{
"Correspondence: C.A. Santos. Faculdade de Ciências Farmacêuticas, Universidade de São Paulo. Av. Professor Lineu Prestes, n.580, Bloco 16, 05508-000

- São Paulo - SP, Brazil. E-mail: carolinasantos@usp.br
} 


\section{INTRODUCTION}

The most common route for drug administration in hospitals is the parenteral one. Parenteral solutions are used as vehicles for drug administration, a procedure that might include more than one drug diluted in one solution. This combination favors drug-drug interactions and occasionally results in less effective drugs or undesired side effects (Trissel, 2010). Another procedure that gives room for drug instability is the extension of the infusion period with the same parenteral bag. When an antibiotic is the drug to be administered, it may lead to damage beyond inefficacy for an individual patient. Suboptimal antimicrobial doses can contribute to microbial adaptation and survival, which allows contamination of the hospital environment with antibiotic-resistant bacteria (Jacobs, 2003). Therefore, it is essential to evaluate the stability of antibiotics under the same conditions used in the hospital, in order to guarantee the therapeutic effect and prevent microbial resistance.

Ceftazidime (Figure 1A) is a $\beta$-lactam antibiotic widely used in hospital care through the parenteral route to treat gram-negative infections (Dumartin et al., 2010). The antibiotic is highly efficient against Pseudomonas aeruginosa, which is the leading cause of hospital-acquired infections (Amyes et al., 1994). Although specific, its plasma half-life is short, with an average of 2 hours (ElShaboury et al., 2007), considering patients with preserved renal function (Dalen et al., 1986). Ceftazidime belongs to the third-generation cephalosporin class, which has maximum in vivo activity when the concentration is four times the Minimum Inhibitory Concentration (MIC) (Mouton, Vinks, 1996). Due to short plasma half-lives, the bactericidal properties from $\beta$-lactam antibiotics are dependent on the time that its concentration remains above the MIC (Fantin et al., 1994). The maximum ceftazidime activity can be sustained over time if: the standard dose is increased; it is given more frequently; or it is administered by continuous infusion (van Zanten, 2009). Continu- ous infusion of ceftazidime was proved to be effective against gram-negative infections, including resistant $P$. aeruginosa and other multidrug resistant strains (Nicolau et al., 2001; Lorente et al., 2007; Moriyama et al., 2009; Moriyama et al., 2010). The choice of continuous infusion can also decrease the antibiotic daily dose (Nicolau et al., 1996) and result in better cost-effectiveness (McNabb et al., 2001). Nevertheless, it is still controversial which dose regimen is the best, due to limited human studies on the subject (Mouton, Vinks, 1996; Roberts et al., 2009).

The antimicrobial properties of ceftazidime can be associated with the bronchodilator properties of aminophylline (Figure 1B), which may improve the treatment of patients with respiratory disorders (Pleasants et al., 1992). Aminophylline is more effective when administered to hospitalized patients through continuous infusion (Budavari et al., 1996; Hilliard et al., 2000), probably due to significant differences in the plasma half-life of theophylline over time (Kubo et al., 1986). The combination of both drugs was reported as stable for up to two hours in parenteral solutions (Pleasants et al., 1992). Since most hospitals do not submit the drug mixture to a rigorous quality control, the association should be carefully studied according to its physicochemical and biological properties. Based on the presented information, this work aimed to evaluate the stability of the ceftazidime-aminophylline association in glucose parenteral solution. The physicochemical stability evaluation was carried for 24 hours by HPLC (High Performance Liquid Chromatography) and the antimicrobial activity was analyzed during the same period by the MIC (Minimum Inhibitory Concentration) test.

\section{MATERIAL AND METHODS}

\section{Material and reagents}

Aminophylline (99.8 \% Medley, Brazil) and ceftazidime ( $99.9 \%$ anhydrous base) were used as the secondary

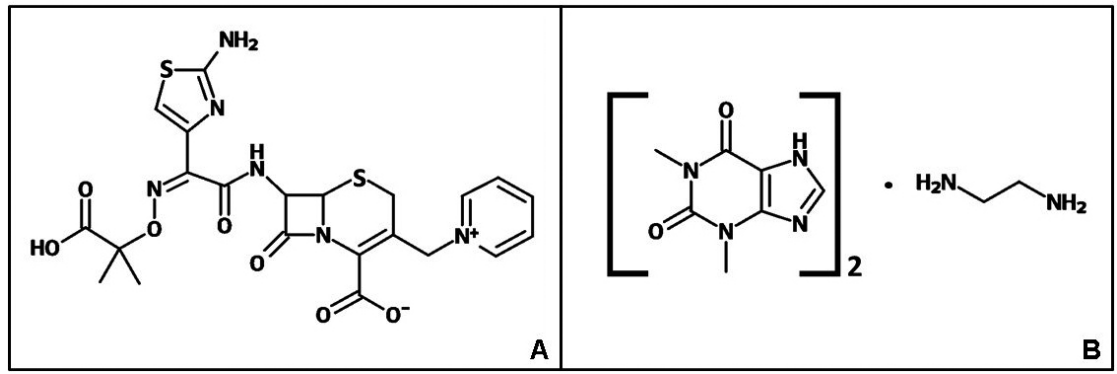

FIGURE 1 - Molecular structure of ceftazidime (A) and aminophylline (B). A - Ceftazidime: $\mathrm{C}_{22} \mathrm{H}_{22} \mathrm{~N}_{6} \mathrm{O}_{7} \mathrm{~S}_{2}$. B - Aminophylline: two molecules of theophylline, $\mathrm{C}_{7} \mathrm{H}_{8} \mathrm{~N}_{4} \mathrm{O}_{2}$, for each molecule of ethylenediamine, $\mathrm{C}_{2} \mathrm{H}_{4}\left(\mathrm{NH}_{2}\right)_{2}$. 
standards for HPLC analysis. All glassware used in the experiments were previously immersed in a $1 \mathrm{M} \mathrm{NaOH}$ solution for $24 \mathrm{~h}$, drained and transferred to a $1 \mathrm{M}$ nitric acid solution for $6 \mathrm{~h}$. After extensive rinsing and $24 \mathrm{~h}$ immersion in purified water (Milli-Q), the equipment was autoclaved for $30 \mathrm{~min}$ at $121^{\circ} \mathrm{C}$. All plastic materials were sterile and disposable. All reagents used were of analytical grade.

\section{Drug solutions}

Ceftazidime (Glaxo Smithkline, Brazil) was diluted $(0.1 \mathrm{mg} / \mathrm{mL})$ in a parenteral solution with $5 \%$ glucose (Aster, Brazil) for the stock solution. The same was made for aminophylline (Hypofarma, Brazil) to a final concentration of $24 \mathrm{mg} / \mathrm{mL}$. Stock solutions were made immediately prior to use at room temperature $\left(25^{\circ} \mathrm{C}\right)$. The stock solutions were then diluted to $320 \mu \mathrm{g} / \mathrm{mL}$ for ceftazidime and $160 \mu \mathrm{g} / \mathrm{mL}$ for aminophylline in parenteral solution, individually or associated with each other (herein called "drug mixture"). The chosen dilutions were based on the plasma concentrations reported in the literature (Trevor, Katzung, Masters, 2001).

\section{Bacterial strains and growth conditions}

Escherichia coli ATCC 25922 and Pseudomonas aeruginosa ATCC 9721 were used as the biological sensors for antimicrobial activity. E. coli was inoculated in Luria Bertani (LB) (DIFCO) broth medium and cultivated at $37{ }^{\circ} \mathrm{C} / 100 \mathrm{rpm} / 24$ hours. P. aeruginosa was inoculated in Trypticase Soy Broth (TSB) broth and also cultivated at $37^{\circ} \mathrm{C} / 100 \mathrm{rpm} / 24$ hours.

\section{pH Determination}

The $\mathrm{pH}$ of all solutions was measured at $25^{\circ} \mathrm{C}$ with a pHmeter (Accumet AR20, Fisher Scientific, USA) before analysis by HPLC and MIC test.

\section{HPLC}

Pharmacopeic methods (USP, 2009) of ceftazidime and aminophylline were combined in a new method described in this item. Reversed-phase HPLC was performed on a Shimadzu LC 10 (software LC solution; Shimadzu, Japan), using a $250 \times 4.6 \mathrm{~mm}$ (internal diameter) column pre-packed with C18 and $12.7 \mathrm{~nm}$ of pore size (Shim-pack VP-ODS, Shimadzu, Japan). The parameters applied were $0.5 \mathrm{~mL} / \mathrm{min}$ flow at $25^{\circ} \mathrm{C}$ and a sample injection volume of $20 \mu \mathrm{L}$, while the mobile phase consisted of $35 \%$ aceto- nitrile, $2 \%$ phosphoric acid $1 \%(\mathrm{pH} 7.0)$ and water (WFI - Water For Injection). Eluted samples were detected at the optimum wavelength (Budavari et al., 1996) for ceftazidime $(255 \mathrm{~nm})$ and aminophylline $(275 \mathrm{~nm})$. This method was developed according to the validation guideline from the International Conference on Harmonization of Technical Requirements for Registration of Pharmaceuticals for Human Use (ICH) (ICH, 2005). The required assays described in the guideline are specificity, linearity and range concentration, accuracy, precision and reproducibility. In order to access specificity in the presence of degradation products, the samples were exposed to $10 \% \mathrm{H}_{2} \mathrm{O}_{2}(2: 1$, $\mathrm{v} / \mathrm{v}$ ) for $1 \mathrm{~h}$, followed by HPLC analysis and comparison with the untreated samples.

\section{MIC determination}

The antimicrobial activity of ceftazidime samples was evaluated by MIC test, according to the guideline from the Clinical and Laboratory Standards Institute (CSLI) (CSLI, 2009). Briefly after the cultivation, both microorganisms were adjusted to $10^{6}$ Colony Forming Units $(\mathrm{CFU}) / \mathrm{mL}$ and distributed in test tubes with two-fold serial dilutions of samples, except for the negative controls. Tubes were then incubated for $24 \mathrm{~h} / 37^{\circ} \mathrm{C}$. Bacterial counts were made in agar plates cultured with the content of the test tubes for 24 hour incubation at $37{ }^{\circ} \mathrm{C}$.

\section{Data analysis}

Chromatograms were obtained using the LC Solution Software (Shimadzu). To confirm the linearity of the HPLC method, a regression line was calculated by the least-squares method. To check the statistical significance of the differences ( $p$ ) between the mean values compared throughout the article, the two-tailed t-test method was applied using the Excel ${ }^{\circledR}$ software, where $p$ values below 0.05 represent statistical significance of the differences between two compared means.

\section{RESULTS}

\section{pH Determination}

The $\mathrm{pH}$ values of all solutions were within the ranges described in the literature. The observed values did not change after 24-hour storage at room temperature. The ceftazidime average $\mathrm{pH}$ was 6.6 , with standard deviation of $0.3(\mathrm{pH}=6.6 \pm 0.3)$. The aminophylline average $\mathrm{pH}=9.5 \pm 0.3$ and the ceftazidime + aminophylline average $\mathrm{pH}=8.30 \pm 0.4$. 


\section{HPLC method development and performance}

The HPLC method presented no statistical differences between the retention times for samples and for the respective standards (ceftazidime $\mathrm{p}=0.13$ and aminophylline $\mathrm{p}=0.06$ ). In addition, peroxide degradation products did not interfere with non-degraded drug peaks (Figure
2). Due to both facts, the developed methodology can be considered specific. The method was linear for both substances, with $\mathrm{R}^{2}$ of 0.99 in the $70-130 \%$ range. Accuracy and precision were also achieved, with standard deviation less than $0.1 \%$ of the sample value. There were no interlaboratorial assays; the reason why reproducibility was not verified.

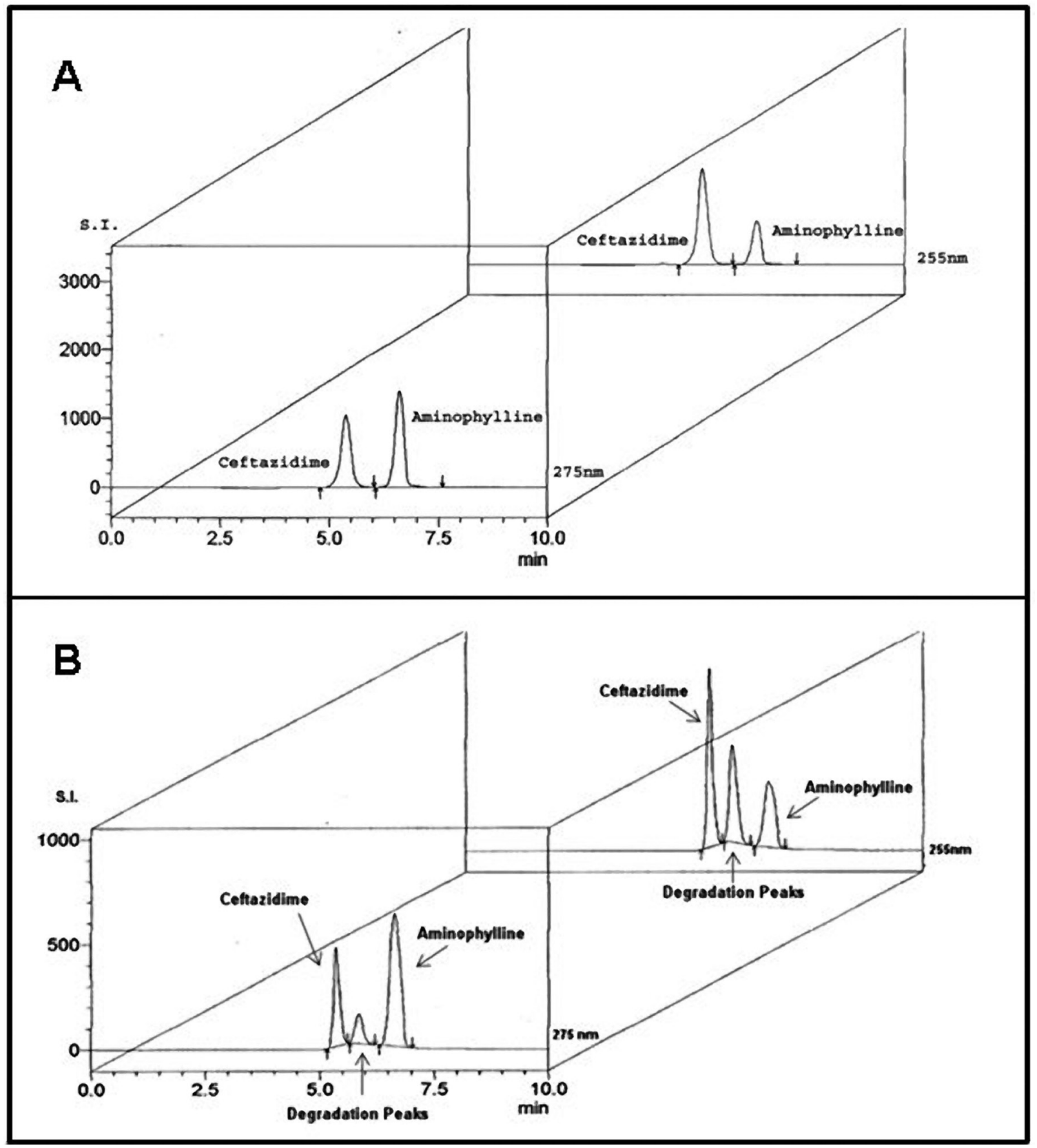

FIGURE 2 - Specificity of the HPLC method for ceftazidime and aminophylline. A) Chromatograms of ceftazidime $(320 \mu \mathrm{g} / \mathrm{mL})$ and aminophylline $(160 \mu \mathrm{g} / \mathrm{mL})$ untreated samples. B) Chromatograms of the same samples treated with hydrogen peroxide. Samples were read at $275 \mathrm{~nm}$, the ideal wavelength for aminophylline detection (front chromatogram of A and B), and at $255 \mathrm{~nm}$, the ideal wavelength for ceftazidime detection (back chromatogram of A and B). S.I.=Signal intensity, min=minutes (retention time). 


\section{Stability of ceftazidime and aminophylline solutions by HPLC}

Triplicate samples of ceftazidime, aminophylline and the drug mixture were diluted in 5\% glucose parenteral solutions, followed by HPLC analysis at 0, 2, 6 and $24 \mathrm{~h}$ after preparation. Drugs were considered stable when concentrations were $\geq 95 \%$ of the values obtained immediately after drug dilution, without mixing (Farina et al., 1999). Aminophylline, was stable at all time periods evaluated (Table I), as it was previously published, regardless of ceftazidime addition.

TABLE I - Stability of aminophylline diluted in 5\% glucose parenteral solution*

\begin{tabular}{ccc}
\hline Time $(\mathrm{h})$ & $\begin{array}{c}\text { Aminophylline } \\
(\mathrm{ug} / \mathrm{mL})^{*}-\end{array}$ & $\begin{array}{c}\text { Aminophylline } \\
\text { (ug/mL)* }\end{array}$ \\
\hline 0 & 167.94 & 165.37 \\
2 & 168.50 & 164.47 \\
6 & 170.90 & 167.40 \\
24 & 169.63 & 164.70 \\
\hline
\end{tabular}

*The reported mean values were collected from three independent experiments, using triplicate samples in each of them. The highest standard deviation was less than $0.02 \%$ of the mean concentration value.

Ceftazidime was also stable when diluted alone. However, its association with aminophylline resulted in a $12.5 \%$ loss of the antibiotic after the $6 \mathrm{~h}$ period (Table II). The decrease in concentration doubled at $24 \mathrm{~h}(25 \%)$, confirming the instability reported for this association (El-Shaboury et al., 2007).

\section{Antimicrobial activity of ceftazidime solutions by the MIC test}

Ceftazidime, aminophylline and the drug mixture were diluted in $5 \%$ glucose parenteral solutions, followed by MIC determination at 0 and $24 \mathrm{~h}$ after preparation
TABLE II - Stability of ceftazidime diluted in 5\% glucose parenteral solution*

\begin{tabular}{ccc}
\hline Time (h) & $\begin{array}{c}\text { Ceftazidime } \\
(\mathrm{ug} / \mathrm{mL})^{*}- \\
\text { drug mixture }\end{array}$ & $\begin{array}{c}\text { Ceftazidime } \\
(\mathrm{ug} / \mathrm{mL})^{*}- \\
\text { individual solution }\end{array}$ \\
\hline 0 & 320.44 & 325.80 \\
2 & 301.54 & 322.86 \\
6 & 280.81 & 322.24 \\
24 & 243.86 & 311.37 \\
\hline
\end{tabular}

* The reported mean values were collected from three independent experiments, using triplicate samples in each of them. The highest standard deviation was less than $0.02 \%$ of the mean concentration value.

(Table III). The tested bacteria were E. coli, a standard sensitive strain, and $P$. aeruginosa, the main target pathogen for this antibiotic. The observed MIC for ceftazidime alone at time zero is within the range found in the literature, but slightly higher than the available means (Neu, Labthavikul, 1982). This MIC value was herein considered as the reference value for comparison purposes $(1.0 \mu \mathrm{g} /$ $\mathrm{mL}$ of ceftazidime for E. coli and $1.9 \mu \mathrm{g} / \mathrm{mL}$ for P. aeruginosa). The MIC value for ceftazidime alone increased four times for $E$. coli and two times for $P$. aeruginosa after $24 \mathrm{~h}$, showing a decrease of the biological activity. The drug mixture revealed negative interactions immediately after the preparation, with a MIC value 15 times higher than the reference value for $E$. coli. This effect was less prominent in the test with $P$. aeruginosa, in which the MIC was 4 times higher than the reference. The analysis after $24 \mathrm{~h}$ showed MIC values 120 times higher than the reference for E. coli and 15 times higher for P. aeruginosa. The aminophylline solution was not bactericidal by itself, as expected.

\section{DISCUSSION}

The physicochemical stability of ceftazidime has been analyzed by HPLC in a variety of solutions. This antibiotic was previously reported as stable in $5 \%$ glucose

TABLE III - Antimicrobial activity of ceftazidime diluted in 5\% glucose parenteral solution

\begin{tabular}{lcccc}
\hline \multirow{2}{*}{ Strain } & \multicolumn{1}{c}{ MIC ceftazidime $(\mu \mathrm{g} / \mathrm{mL})^{*}$ - (individual solution) } & MIC ceftazidime $(\mu \mathrm{g} / \mathrm{mL})$ - Drug mixture* \\
\cline { 2 - 5 } & $\mathbf{0 ~ h}$ & $\mathbf{2 4} \mathbf{~ h}$ & $\mathbf{0 ~ h}$ & $\mathbf{2 4} \mathbf{~ h}$ \\
\hline Escherichia coli & 1.0 & 3.7 & 15.0 & 120.0 \\
Pseudomonas aeruginosa & 1.9 & 3.7 & 7.5 & 30.0 \\
\hline
\end{tabular}

* The reported mean values were collected from three independent experiments, using triplicate samples in each of them. The highest standard deviation was less than $0.01 \%$ of the mean concentration value. 
solution after 24 hours, although a 5\% loss was detected (Moriyama, 2009). The same profile was confirmed in our results.

The spread of HPLC analysis contrasts with the rarity of antimicrobial activity tests applied to ceftazidime stability studies. Our efforts were then directed to determine its antimicrobial activity in the same glucose parenteral solution. MIC values of ceftazidime that inhibit $P$. aeruginosa growth doubled after 24 hours. Since MIC determination is based on a serial 2 fold dilution, the $5 \%$ antibiotic loss detected by HPLC could double the MIC value.

A prominent loss in antimicrobial activity of ceftazidime was observed against E. coli, where the MIC increased four times after 24 hours. This increment cannot be explained by the $5 \%$ antibiotic loss detected by HPLC. Another group also observed the diminished activity of ceftazidime against $E$. coli when media was enriched with glucose (Malouin et al., 1991). They reported that the glucose concentration was directly proportional to PBP 8 (Penicillin Binding Protein) production by E. coli, while it was inversely proportional to the antimicrobial antibiotic activity. Ceftazidime exerts its bactericidal effect by inhibiting the enzymes responsible for cell-wall synthesis, especially PBP3, though it has low affinity to PBP8 (Malouin et al., 1991; Clairoux et al., 1992). It is possible that the augmented BPB8, an enzyme that is not efficiently degraded by ceftazidime, allows the bacteria to continue wall synthesis and scape from antibiotic intervention. Nevertheless, the mechanism has not been elucidated so far and other studies should be carried out in order to evaluate the impact of this phenomenon in vivo.

The combination of ceftazidime with aminophylline resulted in ceftazidime degradation, which initiated between 2 and 6 hours after mixture preparation and peaked at 24 hours, summing $25 \%$ total loss of ceftazidime. Aminophylline is composed by a teophylline-etilenodiamine complex that is stable at basic solutions (Ishiguro et al., 1980), and remained stable when combined with the antibiotic. On the other hand, maximum ceftazidime stability is achieved within the $\mathrm{pH}$ range of 4.5 to 6.5 (Zhou et al., 1995), while its hydrolysis is favored in an alkaline environment (Vilanova et al., 1993). The basic pH of the resulting mixture may by itself explain the significant loss of antibiotic concentration. It is unlikely that both drugs reacted with each other, mainly because aminophylline maintained its physicochemical stability. Accordingly, another cephalosporin combined with the same bronchodilator showed no pharmacokinetic interactions between the two drugs (Szmygin, 1996). The drug mixture in glucose parenteral solution was considered by another group as stable within a $0-2 \mathrm{~h}$ range and unstable within a 6 to $24 \mathrm{~h}$ range; results which were reproduced by our HPLC experiments (El-Shaboury, 2007). However, the same drug mixture at 0 hour presented ceftazidime MIC increase of 15 and 3.9 fold for E. coli and P. aeruginosa, respectively. The hydrolysis of ceftazidime triggered by the basic $\mathrm{pH}$ was probably enhanced by the $37^{\circ} \mathrm{C}$ maintained throughout the MIC tests (Farina et al., 1999). Since the human body maintains the same temperature, it is likely that degradation continues after drug infusion.

The MIC test proved to be a valuable tool when evaluating antibiotics stability in non-standard conditions. The biological method makes it possible to detect antibiotic and vehicle changes in the presence of the target microorganisms and nutritional factors at body temperature. It is important to highlight that MIC was used in our experiments to evaluate the loss of antibiotic activity when compared to an initial solution, but not with a biological reference standard. Therefore, further work is required to include MIC as a routine test for stability, including antibiotic potency determination and method validation.

The previously reported incompatibility of ceftazidime and aminophylline was confirmed by our data. In addition, it was demonstrated that the combination is not stable even immediately after the preparation, due to loss of antimicrobial activity of ceftazidime. Based on these findings, it is not advisable to administer ceftazidime with aminophylline in the same container or by the same intravenous set. Results also suggest that glucose parenteral solution may not be the best choice for a ceftazidime vehicle, especially when a degradation process has already been triggered.

\section{ACKNOWLEDGMENTS}

This work was supported by CAPES (Coordenação de Aperfeiçoamento de Pessoal de Nível Superior, Brazil), $\mathrm{CNPq}$ (Conselho Nacional de Desenvolvimento Científico e Tecnológico, Brazil) and FAPESP (Fundação de Amparo à Pesquisa do Estado de São Paulo, Brazil).

\section{REFERENCES}

AMYES, S.G.; BAIRD, D.R.; CROOK, D.W.; GILLESPIE, S.H.; HOWARD, A.J.; OPPENHIEM, B.A.; PEDLER, S.J.; PAULL, A.; TOMPKINS, D.S.; LAWRIE, S.A. A multicentre study of the in-vitro activity of cefotaxime, cefuroxime, ceftazidime, ofloxacin and ciprofloxacin against blood and urinary pathogens. J. Antimicrob. Chemother., v.34, p.639-648, 1994. 
BUDAVARI, S.; O’NEIL, M.; SMITH, A.; HECKELMAN, P.; OBENCHAIN, J. The Merck Index. 12.ed. New Jersey: CRC Press, 1996. 2520 p.

CLAIROUX, N.; PICARD, M.; BROCHU, A.; ROUSSEAU, N.; GOURDE, P.; BEAUCHAMP, D.; PARR, T.R.; BERGERON, M.G.; MALOUIN, F. Molecular basis of the non-beta-lactamase-mediated resistance to beta-lactam antibiotics in strains of Haemophilus influenzae isolated in Canada. Antimicrob Agents Chemother., v.36, p.1504$1513,1992$.

DALEN, R.; VREE, T.B.; BAARS, A.M.; TERMOND, E. Dosage adjustment for ceftazidime in patients with impaired renal function. Eur. J. Clin. Pharmacol., v.30, p.597-605, 1986.

DUMARTIN, C.; L'HERITEAU, F.; PEFAU, M.; BERTRAND, X.; JARNO, P.; BOUSSAT, S.; ANGORA, P.; LACAVE, L.; SABY, K.; SAVEY, A.; NGUYEN, F.; CARBONNE, A.; ROGUES, A. Antibiotic use in 530 French hospitals: results from a surveillance network at hospital and ward levels in 2007. J. Antimicrob. Chemother, v.65, p.2028-2036, 2010.

EL-SHABOURY, S.R.; SALEH, G.A.; MOHAMED, F.A.; RAGEH, A.H. Analysis of cephalosporin antibiotics. $J$. Pharm. Biomed. Anal., v.45, p.1-19, 2007.

FANTIN, B.; FARINOTTI, R; THABAUT, A; CARBON, C. Conditions for the emergence of resistance to cefpirome and ceftazidime in experimental endocarditis due to Pseudomonas aeruginosa. J. Antimicrob. Chemother, v.33, p.563-569, 1994.

FARINA, A.; PORRÀ, R.; COTICHINI, V.; DOLDO, A. Stability of reconstituted solutions of ceftazidime for injections: an HPLC and CE approach. J. Pharm. Biom. Anal., v.20, p.521-530, 1999.

HILLIARD, T.N.; WITTEN, H.; MALE, I.A.; HEWER, S.L.; SEDDON, P.C. Management of acute childhood asthma: a prospective multicentre study. Eur. Respir. J, v.15, p.11021105,2000

INTERNATIONAL Conference on Harmonisation of Technical Requirements for Registration of Pharmaceuticals for Human use. 2005. ICH Harmonised Tripartite Guideline. Validation of analytical procedures: Text and Methodology. Available at: <www.ich.org/products/guidelines/quality. html>. Accessed on: 13 dec. 2011.
ISHIGURO, Y.; SAWADA, M.; TANAKA, Y.; KAWABE, K. (Photo-stability of aqueous aminophylline solutions under oxygen (author's transl). Yakugaku Zasshi, v.100, p.10481053, 1980.

JACOBS, M.R. Worldwide trends in antimicrobial resistance among common respiratory tract pathogens in children. Pediatr. Infect. Dis. J., v.22, p.109-119, 2003.

KUBO, M.; ODAJIMA, Y.; ISHIZAKI, T.; KANAGAWA, S.; YAMAGUCHI, M.; NAGAI, T. Intraindividual changes in theophylline clearance during constant aminophylline infusion in children with acute asthma. J. Pediatr., v.108, p.1011-1015, 1986.

LORENTE, L.; JIMÉNEZ, A.; PALMERO, S.; JIMÉNEZ, J.J.; IRIBARREN, J.L.; SANTANA, M.; MARTÍN, M.M.; MORA, M.L. Comparison of clinical cure rates in adults with ventilator-associated pneumonia treated with intravenous ceftazidime administered by continuous or intermittent infusion: a retrospective, nonrandomized, open-label, historical chart review. Clin. Ther, v.29, p.24332439, 2007.

MALOUIN, F., CHAMBERLAND, S., BROCHU, N., PARR, T.R. Influence of growth media on Escherichia coli cell composition and ceftazidime susceptibility. Antimicrob. Agents Chemother, v.35, p.477-483, 1991.

McNABB, J.J.; NIGHTINGALE, C.H.; QUINTILIANI, R.; NICOLAU, D.P. Cost-effectiveness of ceftazidime by continuous infusion versus intermittent infusion for nosocomial pneumonia. Pharmacotherapy, v.21, p.549555,2001 .

MORIYAMA, B.; HENNING, S.A.; NEUHAUSER, M.M.; DANNER, R.L.; WALSH, T.J. Continuous-infusion beta-lactam antibiotics during continuous venovenous hemofiltration for the treatment of resistant gram-negative bacteria. Ann. Pharmacother, v.43, p.1324-1337, 2009.

MORIYAMA, B.; HENNING, S.A.; CHILDS, R.; HOLLAND, S.M.; ANDERSON, V.L; MORRIS, J.C; WILSON, W.H.; DRUSANO, G.L.; WALSH, T.J. High-dose continuous infusion beta-lactam antibiotics for the treatment of resistant Pseudomonas aeruginosa infections in immunocompromised patients. Ann. Pharmacother., v.44, p.929-935, 2010. 
MOUTON, J.W.; VINKS, A.A. Is continuous infusion of beta-lactam antibiotics worthwhile?--efficacy and pharmacokinetic considerations. J. Antimicrob. Chemother., v.38, p.5-15, 1996.

NATIONAL COMMITTEE FOR CLINICAL LABORATORY STANDARDS. 2009. M07-A8: Methods for dilution antimicrobial susceptibility tests for bacteria that grow aerobically. Available at: <www.clsi.org $>$. Accessed on: 13 dec. 2011.

NEU, H.C. In-vitro activity of ceftazidime, a beta-lactamase stable cephalosporin. J. Antimicrob. Chemother., v.8, suppl.B, p.131-134, 1981.

NEU, H.C, LABTHAVIKUL, P. Antibacterial activity and beta-lactamase stability of ceftazidime, an aminothiazolyl cephalosporin potentially active against Pseudomonas aeruginosa. Antimicrob. Agents Chemother., v.21, p.1118, 1982.

NICOLAU, D.P.; MCNABB, J.; LACY, M.K.; QUINTILIANI, R.; NIGHTINGALE, C.H. Continuous versus intermittent administration of ceftazidime in intensive care unit patients with nosocomial pneumonia. Int. J. Antimicrob. Agents, v.17, p.497-504, 2001.

NICOLAU, D.; NIGHTINGALE, C.; BANEVICIUS, M.; FU, Q.; QUINTILIANI, R. Serum bactericidal activity of ceftazidime: continuous infusion versus intermittent injections. Antimicrob. Agents Chemother., v.40, p.61-64, 1996.

PLEASANTS, R.; VAUGHAN, L.; WILLIAMS, D.; FOX, J. Compatibility of ceftazidime and aminophylline admixtures for different methods of intravenous infusion. Ann. Pharmacother., v.26, p.1221-1226, 1992.
ROBERTS, J.A.; WEBB, S.; PATERSON, D.; HO, K.M.; LIPMAN, J. A systematic review on clinical benefits of continuous administration of $\beta$-lactam antibiotics. Crit. Care Med., v.37, p.2071-2078, 2009.

SZMYGIN, K. The influence of selected antibiotics on the central action of aminophyllines-experimental studies. Pneumononol. Alergol. Pol., v.64, suppl. 1, p.63-69, 1996.

TREVOR, A.J; KATZUNG, B.G.; MASTERS, S.B. Katzung's Pharmacology: examination and board review. 6.ed. Boston: McGraw-Hill; Appleton \& Lange, 2001.526 p.

TRISSEL, L.A. Handbook on injectable drugs. 16.ed. Bethesda: American Society Health-System Pharmacists, 2010. p. 304-310.

USP. United States Pharmacopeia and National Formulary. USP 32 - NF 27. Rockville, MD: United States Pharmacopeia Convention, 2009. p.1522-1857.

VAN ZANTEN, A.R.H. The jury is still out on continuous infusion of $\beta$-lactam antibiotics in intensive care patients. Crit. Care Med., v.37, p.2137-2138, 2009.

VILANOVA, B.; MUNHOZ, F.; DONOSO, J.; BLANCO, F.G. HPLC and1H-NMR studies of alkaline hydrolysis of some 7-(oxyiminoacyl)cephalosporins. Helv. Chim. Acta, v.76, p.2789-2802, 1993.

ZHOU, M, NOTARI, R.E. Influence of $\mathrm{pH}$, temperature, and buffers on the kinetics of ceftazidime degradation in aqueous solutions. J. Pharm. Sci., v.84, p.534-538, 1995.

Received for publication on $25^{\text {th }}$ April 2012 Accepted for publication on $24^{\text {th }}$ August 2012 